\title{
IN MEMORIAM: ROGER ASSELINEAU, 1915-2002
}

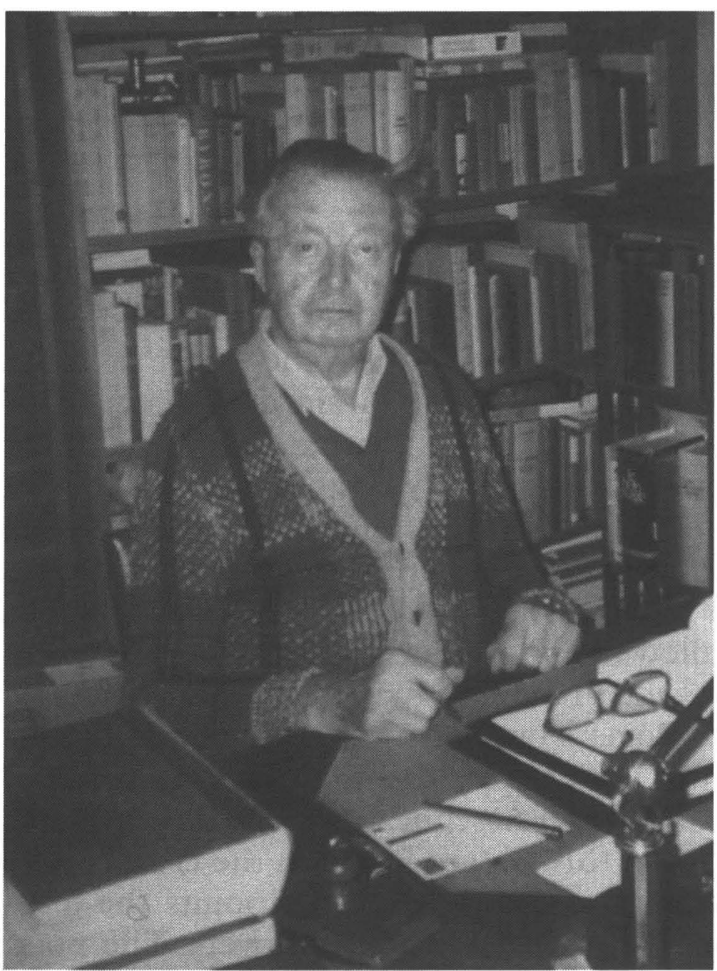

Photograph of Roger Asselineau in his study, taken November 2001 by daughter Claire Asselineau.
Roger Asselineau, one of the giants of Whitman studies, died on July 8, 2002 , in Paris. He was 87 years old. His death marks the end of an era in Whitman scholarship. $\mathrm{He}$ was the last surviving member of the Advisory Editorial Board for The Collected Writings of Walt Whitman, organized in 1955 to oversee the publication of an authoritative edition of all of Whitman's writings, a project that is still ongoing. At the time the project began, Asselineau's magisterial work, L'Evolution de Walt Whitman, had just been published, but the English translation (The Evolution of Walt Whitman) was still some years off. In the foreword to the 1999

University of Iowa Press reprinting of Evolution, I tried to suggest the enormous influence Asselineau's book has had on the field, and I ended by saying that if you put The Evolution of Walt Whitman on your bookshelf of Whitman criticism and arranged the volumes chronologically, all the books to the right of Asselineau's would now constitute the evolution of The Evolution of Walt Whitman. His work is so thoroughly woven into talks and articles and books, and his ideas are so commonly debated, altered, and recombined, that The Evolution has now become the common great-grandparent of a vast range of recent Whitman commentary. 
I first met Roger in New York in the early 1980s, when Gay Wilson Allen introduced me to him over a drink at an MLA convention. We soon began a long correspondence that continued up to the last week of his life; my final letter from him arrived after I had already received the news of his death. Over the years, our common interest in Whitman allowed us to travel together at conferences in California, France, Italy, and China. He was honored at the Centennial Conference in Iowa in 1992 as a "centennial scholar" and at the Whitman 2000 conference in Beijing as a "millennial scholar." He was indefatigable-always anxious to take the extra trip, tour the forgotten monastery, carry on the discussion over one more drink late at night. At the Beijing conference in 2000 , at age 85 , he led the participants off the bus on the way to the Great Wall.

Roger was an active member of the Editorial Board of this journal from its beginnings. His last book review for $W W Q R$ was published in this summer's issue, appearing just days after his death. His final essay on Whitman, a lovely summing up of his lifetime's encounter with the poet, will appear this fall in Whitman East and West, the collection of essays growing out of the Beijing conference. It is an indication of his vigor that he was doing so much work literally up to the final weeks of his life: like Whitman, he continues to speak eloquently to us after his death, and his words will continue to do so for many years to come.

Roger had the soul of a poet: it is what energized his own perceptions of Whitman and what allowed him to translate Whitman's work so effectively into French, making the French language sing with Whitman's spirit. That soul is evident in Roger's own poetry, the most recent volume of which appeared just this year. It bore the title Miettes et Miracles, a title that captures the essence of Roger Asselineau's and WaltWhitman's view of the world: the miracles in this life are found in the crumbs, the bits, the fragments-what Whitman called at various points the leavings, the odds and ends, the drift and debris, the leftovers. The poet, Whitman said, "hardly knows pettiness or triviality," because he knows how to see the miracle in what others see as just dross: "If he breathes into any thing that was before thought small it dilates with the grandeur and life of the universe." Roger Asselineau had that same miraculous ability to transform the everyday into the transcendent. It was a skill he honed out of the nearly six decades of his life that he considered a gift after his escape from a Nazi death-sentence for his activities in the Resistance during World War II. After he left the prison that he had thought would be the last thing he would know, the small things in life suddenly began to seem very important indeed, and he sculpted out of his "leftover" life a new kind of contingent faith - a "transcendentalist constant"- that became a source of stability in his life. It is why he loved Whitman, who discerned a miracle in leaves of grass. 
What follow are tributes to this remarkable individual from some of the scholars worldwide who knew him and learned from him.

-Ed Folsom

ferome Loving:

Roger Asselineau worked almost right up to the moment of his death at age 87. He reminds me of John Dewey, who remarried at that age and even started a new book. When I returned home from a research trip to the University of Virginia four days after receiving news of Roger's death, his last letter was waiting for me. His health had worsened considerably, so much so that he didn't think we would ever meet again in the States, as he fondly called the country to whose literature he contributed so much analysis and celebration. Now he could write only book reviews, he said, but his tone also hinted ever so slightly that things might improve. He was an optimist. When he and his wife Paule returned from a vacation in Greece in their early eighties, he announced, "We'll have to go back!"

I knew Roger for a quarter of a century. Although he was old enough to have been my father, because of his perennial youthfulness I never considered him anything but a brother and a soulmate. At the suggestion of Gay Wilson Allen, I initiated a correspondence with Roger in 1976. Two years later we met face to face in Paris. I was on my way back with my young family from an exhausting if always eventful and exciting semester as a Fulbrighter in the old Soviet Union. Roger had arranged our accommodations in a hotel at Place Odéon on the Left Bank. I will never forget his walking down the rainy street to greet and escort me to one of his favorite restaurants on the Boulevard St. Michel. Even though he was a famed scholar and the biographer of Walt Whitman, it was easy to talk to him. We got along naturally from the first because his manner was somewhat self-effacing and certainly genial. He came to my university as a visiting professor in 1982, and I went to his at the Sorbonne two years later. Through his auspices, I returned to Paris on my second Fulbright to lecture at the Sorbonne Nouvelle in 1989-1990. In between, we met at many literary conferences both in the States and Europe.

It was a privilege to walk the streets of Paris with him. Roger was an inveterate walker who needed no other exercise to keep him upright and agile into his early eighties. Once we walked to the French Mint, where I purchased a bronze medallion stamped with the flowing image of Walt Whitman. Often during my first extended visit to Paris we strolled in the Jardin du Luxembourg along its crushed rock pathways or down St. 
Jacques Boulevard from the Sorbonne to the quai and across the Seine to Shakespeare and Company, which stood in the shadow of Notre Dame. Its owner, not Sylvia Beach of the original and more famous bookstore of the same name, was George Whitman, who claimed he was related to the Poet of Democracy (an assertion he later gave up). On another time and another visit, I believe in 1986, we were sitting outside the Sorbonne having a glass of wine as a parade went down St. Michel. It reminded Roger of the day he was released from prison at the end of World War II. He had been incarcerated and sentenced to death for his work in the Resistance, work which also involved helping downed U.S. pilots escape Nazi-occupied France. His sentence was "commuted" by the American invasion of Paris. The day of his release he and others were transported in an open wagon, and nobody along the Boulevard knew for some time that they were released prisoners. After all the terrific hardship of almost two years of being confined in a stuffy prison cell with a slit of a window for air, an enclosed compartment about six by eight feet with two other prisoners, he was greeted as if nothing at all had happened to him. Ironically, after the war he ended up living in a house in a Paris suburb across the street from the prison!

In the summer of 1999 Roger visited me in Philadelphia, where I was beginning the research for a biography of Theodore Dreiser. Just two blocks from the house I was renting stood the famous penitentiary of the Eastern District of Pennsylvania. It had housed Al Capone and other notorious prisoners, but its claim to our attention was that it had been built by the Quakers as one of the first prisons intent on rendering its inmates truly penitent of their crimes. Its cells were large, but the inmates in the early nineteenth century were confined to solitary existences for two years. Dreiser's Frank Cowperwood of The Financier does a stretch there for embezzlement. As we toured the crumbling cells that summer day, it suddenly occurred to me that Roger had once been a prisoner himself. Yet he readily entered the miniature dungeons to investigate them, while I myself held back from the horror of it all. Afterward, we went back to the house and he talked about his imprisonment for about an hour.

At the Sorbonne Roger Asselineau was in his day its Central Man, as Emerson would say, as the leading scholar of American literature. When I lectured at a number of universities in France, I discovered that the senior Americanist in almost every case had done his or her doctoral studies under Roger. Roger, of course, wrote one of the finest biographies of Walt Whitman - far superior to his French predecessors in Whitman biography, Léon Bazalgette and Jean Catel, who had particular axes to grind. Roger wrote his biography first as his dissertation at the Sorbonne and, in accord with French tradition, treated the writer and the work in separate sections-in Roger's case, separate volumes. 
He was one of the first modern scholars to suggest that Leaves of Grass grew in part out of the anxiety the poet suffered from his alleged homosexuality. It continues to shine valuable light on Whitman, so much so that University of Iowa Press recently reissued it with a foreword by Ed Folsom.

He will be missed. I last saw Roger in the summer of 2001. At 86 he joined my wife Cathy and me on a train ride from Paris across Germany to Bamberg to attend the triennial meeting of the International Association of University Professors of English. Roger was one of the earliest members of this post-war organization founded to bring the warring countries of Europe back together again on a cultural basis. On the way we spent two days in Mayen, the hometown of Dreiser's father, which like much of Germany had been almost totally destroyed by allied bombs and today is almost miraculously restored. Roger bore no grudge against the Germans. He was all for civilization, wherever he found it.

- College Station, Texas

\section{Walter Grünzweig:}

At a time when the "internationalization of American Studies" is rapidly becoming a mega-trend (albeit often rather provincial in the results it creates), it is important to remember those early giants in the field who actually lived scholarly lives between different languages, countries, and continents. Of all of them, Roger Asselineau is perhaps the most noteworthy. As was the case with so many Americanists of his generation, his interest in the literature and culture of the United States grew out of deep political convictions, in his case shaped and toughened by Hitler's dungeons. The combination of patriotism with an international and internationalist outlook is natural for most, if not all, antinazi activists and especially for the résistance where members of many nationalities, religious creeds, and political convictions joined the cause of humanity.

In this sense, his work-although often not explicitly politicizedis deeply political. Roger is one of the great European humanists who understood literature and culture as possibilities for transcending narrow and constraining versions of national identity. His interest in America and American culture was also an expression of a global vision-of one who knew that we should not, and cannot, stop at a united Europe.

Reviewing my correspondence with him dating from 1987, I cannot but be amazed at the generosity and helpfulness of this great scholar towards a relatively young and, especially to him, unknown Austrian scholar. At the time, I was researching the relationships between French 
and German Whitmanites, and he actually went to Parisian libraries and manuscript dealers for me to search for the whereabouts of papers of Whitman's French "prophet," Léon Bazalgette. He provided me with many helpful leads for a history of the international Whitman networkwhich is yet to be written.

For many European scholars, he functioned as a role model. When I was a student, and then a young scholar, of American literature, it was relatively difficult for European scholarship on American literature to be heard in the U.S. Whether this was so because of the sometimes hermetic nature of American scholarship or the inhibitions of Europeans is difficult to say. Probably it was a mixture of both. But Roger Asselineau proved to us that Europeans could make themselves heard in American scholarship, that they would be heard and accepted in the New World. In that way, he was both an example and a trail blazer and, most importantly, encouraged us to try for ourselves.

It is, of course, not surprising that such an early intervention by a European scholar in America occurred in the area of Whitman scholarship, namely with the publication of the The Evolution of Walt Whitman in 1960. Whitman scholars - foremost, of course, Gay Wilson Allenreceived this extraordinary European scholar in the friendly spirit that had always characterized this community, and Roger Asselineau proved to be a most congenial member.

The intensity of our feeling of loss testifies to the extraordinary presence of this scholar, colleague, and friend. At the same time his work is so much a part of the texture of our own that he is, and will remain, with us permanently.

—Dortmund, Germany

Betsy Erkkila:

Roger Asselineau was one of the founding figures of American literary studies in France. He was not only a great scholar; he was also a grand, affectionate citizen of the world who embodied the very spirit of Whitman's "Salut au Monde!" I first met Roger when I was a Fulbright scholar in France working on my dissertation on Whitman and the French. I wrote to him, and although he did not know me, he invited me to his home for lunch where I also had the pleasure of meeting his wife, Paule. Roger took the time to carefully read and comment on early chapters of my study of Whitman among the French. He encouraged me and made me feel that I had something important to contribute to Whitman studies. He showed me his library, which was full of books in a multiplicity of languages that had been sent to him by Whitmanian writers 
and scholars throughout the world. He made me want to be a part of the international community of Whitman scholars over which he and Gay Wilson Allen presided for many years.

For Roger Asselineau, the essential Whitman was the spiritual Whitman. As I look back on Roger's extraordinary life, I realize that his emphasis on the mystical dimensions of Whitman's life and work seems all the more striking because he lived the kind of politically daring and heroic life that many of us who write about the historical and political contexts of American literature have never known. He worked with the French Resistance in World War II and was sentenced to death by the Nazis. Roger Asselineau was a great scholar of the spirit who knew and lived the risks of a politically committed life. As a person and a scholar, he left an extraordinary legacy that will be missed and remembered by friends and comrades throughout the world.

"Blossoms and branches green to coffins all I bring,

For fresh as the morning, thus would I chant a song for you $\mathrm{O}$ sane and sacred death."

-Evanston, Illinois

\section{Wynn Thomas:}

Even after spending a brief period in his company, I realize I did not know Roger Asselineau. As an undergraduate, I had 'known' him as a Set Author, one of those remote imposing figures whose scholarly studies were identified as essential reading in American Literature. And when I saw him at the Iowa Centenary Conference in 1992 remote at first he remained-aloof, patrician, dignified, the very embodiment of a founding figure of Whitman scholarship and one of the grand seigneurs of American studies on the Continent. In other words, I saw him through a haze of Gallic and cultural stereotypes. Dining with him after the conference dispersed the haze a little; it was possible to discern a charm, an underlying warmth, and to be fascinated by the mystique of the long foreground to his Whitman studies - his own background in the Resistance, the political (as much as cultural) climate of postwar France that fostered an interest in things American; and it was also possible to feel the generation gap, of which he himself seemed acutely conscious, between his generation of scholars and mine-the emerging generation he partly mistrusted because it seemed infected with an interest in (French!) theory and the New Historicism. My memories of that occasion are of his elegant geniality and the graciousness with which, learning of my own biculturalism (Welsh and English), he presented me with a signed copy of some of his translations of English poetry into French. Insofar 
as any studies of Whitman may be regarded as definitive- and he belonged to a tradition of "pre-post-structural" French scholarship that thought in these authoritative terms - his certainly are: they permanently changed the terms of Whitman criticism and remain a daunting standard against which all other criticism will continue to be judged, and will almost always, alas, be found wanting.

-Swansea,Wales

Kenneth M. Price:

In the same semester that I joined the faculty at Texas $A \& M$ as a beginning assistant professor, Roger Asselineau also came to A\&M to serve as a Visiting Distinguished Professor. One might think: "now there's a great opportunity for a beginning Whitman scholar!"Well, yes and no. The problem was that, in the previous spring, American Literary Realism had asked me to write a review of Roger's The Transcendentalist Constant in American Literature, and I had done so, wholly unaware, of course, that Roger was slated to visit College Station the next fall.

A great admirer of Roger's Evolution of Walt Whitman, I found the volume I reviewed to be deeply disappointing. So, with the zeal of a fresh $\mathrm{PhD}$, I pointed out some of the weaknesses of the book, which didn't live up to the promise of its title. It was only later that I came to learn that Roger had originally given the volume a looser title (Dreaming in the Grass, and other Essays), and had been overruled by a publisher hoping for greater sales.

Nothing about the review is significant now. What is significant, however, is Roger's response to it because of what it tells us about him. That is, he was gracious, helping to ease me into professional life both during that term and later by writing letters of support for grant and job applications. Far from being vindictive, he was positively helpful.

From this curious beginning, a nice friendship developed. I'll always remember with great fondness dining with Roger in a Paris café (two Whitman scholars not altogether at home at the Edith Wharton conference we were attending). And I'll also always value the memory of visiting Roger in his home in Antony and his warm hospitality there. Roger Asselineau was a tremendous scholar and a large-hearted, generous man. I will miss him. 


\section{Robert Strassburg:}

When Roger Asselineau died in July, we lost one of Europe's great men of letters, who was also a beloved parent, poet, teacher, and friend. His monumental work was The Evolution of Walt Whitman, but his expertise extended far beyond Whitman into studies of Dreiser, Hemingway, O'Neill, Williams, Poe, and Crèvecoeur. Much is known of Roger Asselineau the scholar, but little is known about Asselineau the poet, whose lyrical, whimsical, and tender utterances-found in over two hundred poems - have inspired composers Jean-Jacques Werner and Robert Strassburg to set some of them to music. Of his method of poetic composition, Roger has written: "I never write a poem unless there is a spark in my mind produced by the clash of two words, or, more often, by sudden encounters with something unexpected and therefore wonderful in the physical world, or in my internal universe." Roger may be France's best unknown poet, and his riches await poetry lovers everywhere. Here, in translations by Kenneth and Paul Christensen, are two of his poems:

\section{Night Sky}

Tonight the stars

Look down at me like eyes

But the eyes are vacant

Because the stars look without seeing me.

\section{Carpe Diem}

Seize the day

Don't trust tomorrow

Love fully the one you adore.

Hail and farewell, dear friend!

—Laguna Hills, California

Paul Christensen:

My wife Cathy and I had lunch with Roger ten days before his death, at his house in Antony, just outside Paris. We were an hour late getting to the suburbs from the 18th, and he was a little upset with usnot because of the hour, but because his maid Maria, a Portuguese housekeeper he had employed for years, had to leave to attend her kids. So we 
dined without service and had a pleasant quiet hour sipping a Burgundy from his larder bearing a label that said Vin de Chevalier Asselineau, something his wine man did for his better customers, he told us. We ate our melon with port, then roast lamb with potatoes, and he passed a cheese platter laden with sheep and goat cheese, some Camemberts and a Gouda. I recalled the large platters his late and beloved wife Paule used to serve years ago, and he closed his eyes and let out an appreciative sigh at the memory. "Ah yes, mine is not as generous, I'm afraid," he said with characteristic modesty.

Roger was a bit tired, I thought. When I asked how he was feeling, he told us of a time not too far back when he was out walking and looked up at the sky at a sound he heard and felt such a powerful pain shoot through him that it shocked and frightened him. He said he swooned and lost his balance for a moment, and it worried him. He had angina pectoralis, he told us, and suffered in cold weather. His sideboard was loaded with medicines, and he was suffering some prostate problems as well.

We went out to his balcony and talked for a long time about his garden, the kids who lived not too far away, his pleasure in the little pond, and the sense he had that he lived in a park, as he pointed to the lush backyards around us. We went below and he showed us the many translations into French of Whitman's Leaves, his own prominent among them. We also chatted about his little poetry book, Miettes et Miracles [Crumbs and Miracles], which expressed an ironic, dreamy side of Roger's character. He loved mirages, paradoxes, and the weather; and all this and more are reported in his daybook poems, more notes and apercus than actual lyric forms. His daughter Claire, a bookbinder at the Louvre, had bound the work in marbled endpapers and a leather cover, and we handled it with appropriate reverence. I had published an earlier collection of his work, Poesies Incomplètes [The Incomplete Poems], translated by my father and me, which flew all over the map in observing himself and others in funny, sometimes absurd situations, or things that amused him. But he dismissed the new book as a mere trifle; he and I both knew it was more than that, a kind of garden of pure and simple images against all the furies whirling in our age.

$\mathrm{He}$ also produced a brief review of my book, West of the American Dream, which was very complimentary and precise. It would appear soon in Etudes Anglaises. He preferred talking about other people's work, and he would have gone on about me except I could tell he was wearying a bit and changed the subject. He was enjoying himself but he was longing for his rest. When we bid farewell to one another, a vague promise was made that he would swing east to our little village in Provence on his way to the coast and visit, perhaps have lunch. He would have walked us to the station but I told him to stay home, and he readily agreed to his 
nap. It was three o'clock. I had brought a camera with me and we took several pictures of Roger on the balcony, with Cathy, then me, then one by himself. I have them now, and his eyes are a little withdrawn. Perhaps it was his modesty again, since he did protest once that he wasn't a fit subject for a picture. But he posed and was pleased that I was snapping away at him.

When we left, I told Cathy I didn't think we would ever see him again. I felt he had come to the end of his road. On news of his death from Jerry Loving, I could only feel relief. He was worn out, he was uncertain of his body, and he was beginning to suffer. He was charming as ever, and self-possessed, and humorous through our lunch, but he was also thinking of other things. When we talked about his time as a prisoner at La Fraisne Prison in Paris, awaiting execution, he replied to a question: "I wanted to be shot! Not go to a camp and linger on and then die. Oh no, I expected to be shot and would have protested any other finding of the court at Berlin, where I had sent my appeal. If they had decided to send me to the camps, I would have protested anew." Roger had been a prominent figure in the Resistance during World War II. He was helping ferry downed English pilots back to the British Isles and someone had listed him in an address book that fell into Nazi hands. He was arrested at his mother's house, and he and his mother were taken into custody. He never made much of his time as a resistance fighter, but France knew and held him in high esteem for his bravery.

He didn't want to linger in any sort of twilight of fate, so this is best. $\mathrm{He}$ died in full possession of his faculties, and that is cause for our joy and comfort, I think. He died as he was, a very good man. 